\title{
Pengaruh Profitabilitas, Likuiditas, Dan Leverage Terhadap Kebijakan Dividen Kas \\ (Studi Pada Perusahaan Real Estate Dan Properti Yang Terdaftar Di Bursa Efek Indonesia Periode 2013-2015)
}

\author{
Harrys Amdana Andika Putra \\ e-mail: harrys.malang23@gmail.com
}

\author{
Anwar Made \\ Eris Dianawati \\ (Program Studi Akuntansi, Fakultas Ekonomika dan Bisnis, Universitas Kanjuruhan, Malang)
}

\begin{abstract}
ABSTRAK
Penelitian ini bertujuan untuk mengetahui seberapa besar pengaruh profitabilitas, likuiditas, dan leverage terhadap kebijakan dividen kas. Penelitian ini menggunakan jenis data kuantitaif deskriptif dan sumber data yaitu sekunder. Sampel penelitian ini sebanyak 49 perusahaan real estate dan properti dengan menggunakan teknik sampling dengan purposive sampling. Teknik pengumpulan data dari internet, jurnal, buku, artikel, dan skripsi terdahulu. Variabel yang digunakan yaitu variabel independen meliputi profitabilitas menggunakna rumus rasio NPM, ROI, dan ROE, likuiditas menggunakan rumus rasio QR dan CR, dan leverage menggunakan rumus rasio DAR dan DER. Sedangkan kebijakan dividen kas menggunakan rumus dividen tunai dibagi jumlah saham perusahaan. Teknik analisis data yeng digunakan adalah regresi linier berganda.

Hasil penelitian ini menunjukkan bahwa profitabilitas yang diprosikan oleh return on investment (ROI), dan leverage yang diperoksikan debt to asset ratio(DAR) dan debt to equity ratio (DER) secara parsial tidak berpengaruh signifikan terhadap kebijakan dividen kas. Namun profitabilitas yang diproksikan net profit margin (NPM) dan return on equity (ROE), likuiditas yang diproksikan current ratio $(\mathrm{CR})$ dan quick ratio $(\mathrm{QR})$ berpengaruh positif signifikan terhadap kebijakan dividen kas. Sedangkan secara simultan NPM, ROI, ROE, CR, QR, DAR, dan DER berpengaruh signifikan terhadap kebijakan dividen kas.
\end{abstract}

Kata kunci : Profitabilitas, Likuiditas, Leverage, Kebijakan Dividen Kas, Real Estate dan Properti.

\section{ABSTRACT}

This study aims to determine how much influence the profitability, liquidity, and leverage of cash dividend policy. This research uses descriptive quantitative data types and secondary data sources. The sample of this research were 49 real estate and property companies using a sampling technique with purposive sampling. Data collection techniques from the internet, journals, books, articles, and previous thesis. The variables used are independent variables including profitability using the formula of NPM, ROI, and ROE ratio, liquidity using the formula of $\mathrm{QR}$ and $\mathrm{CR}$ ratio, and leverage using the DAR and DER ratio formula. Whereas the cash dividend policy uses the cash dividend formula divided by the number of company shares. The data analysis technique used is multiple linear regression.

The results of this study indicate that the profitability which is posited by return on 
investment (ROI), and leverage which is predicted to be a debt to asset ratio (DAR) and debt to equity ratio (DER) partially have no significant effect on cash dividend policy. However, profitability proxied by net profit margin (NPM) and return on equity (ROE), liquidity which is proxied by current ratio $(\mathrm{CR})$ and quick ratio $(\mathrm{QR})$ has a significant positive effect on cash dividend policy. While simultaneously NPM, ROI, ROE, CR, QR, DAR, and DER significantly influence cash dividend policy.

Keynotes : Profitability, Liquidity, Leverage, Cash Dividend Policy, Real Estate Dan Property.

\section{PENDAHULUAN}

Dalam kegiatan perusahaan pastinya akan mendapatkan profit yang nantinya akan dibagikan sebagai dividen pada setiap pemegang saham. Salah satunya adalah kebijakan dividen kas yang digunakan sebagai tolak ukur para pemegang saham apakah perusahaan tersebut memiliki profit yang lebih banyak atau sedikit. Kebijakan dividen kas tersebut juga mempengaruhi para penanam saham apakah mereka ingin menanamkan sahamnya pada perusahaan tersebut atau tidak karena kebijakan dividen kas salah satu penilaian para pemegang saham untuk menanamkan sahamnya. Para pemegang saham pun lebih menyukai dividen dari pada capital gain, karena dividen lebih menjanjikan sesuatu yang lebih pasti. Sesuai dengan teori bird in the hand theory menyatakan bahwa investor lebih menyukai dividen yang naik daripada turun. Alasan utama lebih menyukai dividen yang naik adalah adanya kepastian, sedangkan mengharapkan kenaikan harga saham adalah sesuatu yang belum pasti. Oleh karena itu, dividen dianggap menawarkan kepastian yang lebih baik dibandingkan capital gain.

Pemilihan populasi terdapat adanya program pemerintah ditahun 2015 yaitu program 1 juta rumah untuk masyarakat yang didistribusikan ke 34 provinsi. Adanya progam tersebut setidaknya dapat memberikan keuntungan bagi perusahaan-prisahaan real estate yang terdaftar di BEI khususnya. Selain itu program tersebut didukung dengan adanya perubahan regulasi peraturan pemerintah untuk mewujudkan program pemerintah 1 juta rumah yaitu PERMENDAGRI N0. 32 tahun 2010, PERMENPERYAT No. 7 tahun 2013, PP No 99 Tahun 2013, KEPRES RI No. 14 Tahun 1993,

KEPMENKUE No 290/PMK.05/2010, PP No 15 Tahun 2004, PP No. 31 Tahun 2007, PP No.1 2008, Peraturan OJK No 13/6/DPNP Tahun 2011, dan PP mengenai jaminan Pemerintah.

Investor lebih melihat dari kinerja keuangan perusahaan yang tercermin dalam laporan keuangan. Investor dapat menganalisis dari profitabilitas, diukur dengan laba bersih setelah pajak dibagi total asset atau dengan Return On Asset (ROA), bila ROA semakin besar maka pendapatan dividen juga meningkat. Likuiditas (diukur dari Current Ratio), bila Current Ratio semakin besar maka menunjukkan kemampuan perusahaan dalam memenuhi kewajiban jangka pendeknya (membayar dividen yang terutang),Leverage, diukur dari (Debt to Equity Ratio), bila leverage operasi perusahan atau keuangan tinggi akan memberikan dividen yang rendah.

Terdapat penelitian yang memiliki hasil berbeda mengenai hubungan maupun pengaruh dari likuiditas, leverage, dan profitabilitas, terhadap kebijakan dividen kas. Penelitian Indah S, Ratna A, dan Tri Hesti U, 2010 menunjukkan kinerja keuangan perusahaan tidak berpengaruh signifikan terhadap kebijakan dividen, sedangkan menurut Ahmad S dan Nur Fadjrih A bahwa menyatakan secara parsial hanya return on assets (ROA) yang berpengaruh signifikan terhadap 
kebijakan dividen. Menurut Darminto, 2008 menyatakan bahwa secara parsial hanya variabel profitabilitas dan struktur modal yang mempunyai pengaruh signifikan terhadap kebijakan dividen, sedangkan variabel likuiditas dan struktur kepemilikan saham tidak berpengaruh signifikan terhadap kebijakan dividen. Dan juga menurut penelitian yang dilakukan oleh Rialdi Nurraiman, 2009 menyatakan bahwa Profitabilitas dalam hal ini NPM tidak berpengaruh signifikan terhadap dividend payout ratio, Profitabilitas dalam hal ini ROA berpengaruh positif signifikan terhadap dividend payout ratio, Likuiditas dalam hal ini CR berpengaruh positif signifikan terhadap dividend payout ratio, Leverage dalam hal ini DAR tidak berpengaruh signifikan terhadap dividend payout ratio, dan Leverage dalam hal ini DER tidak berpengaruh signifikan terhadap dividend payout ratio, sedangkan penelitian Uswatun Khasanah, 2009 menyatakan bahwa likuiditas dan profitabilitas secara bersama-sama berpengaruh terhadap kebijan dividen.

\section{Tujuan Penelitian}

Setiap aktivitas yang dijalankan dalam mengadakan penelitian mempunyai tujuan.

Adapaun tujuan penelitian ini yang dikemukakan adalah:

a. Untuk mengetahui profitabilitas berpengaruh secara parsial terhadap kebijakan dividen kas.

b. Untuk mengetahui likuiditas berpengaruh secara parsial terhadap kebijakan dividen kas.

c. Untuk mengetahui leverage berpengaruh secara parsial terhadap kebijakan dividen kas.

d. Untuk mengetahui profitabilitas, likuiditas, dan leverage berpengaruh secara simultan terhadap kebijakan dividen kas.

\section{TINJAUAN PUSTAKA}

\section{A. Tinjauan Teoritik}

1. Kebijakan Dividen Kas

Dividen menurut Sunariyah (2010:48) menyatakan bahwa dividen adalah pembagian keuntungan yang diberikan perusahaan penerbit saham tersebut atas keuntungan yang dihasilkan perusahaan.

2. Teori Keagenan

Tujuan perusahaan adalah untuk meningkatkan atau memaksimalkan kemakmuran principal (pemegang saham). Tetapi pada kenyataannya tidak jarang agent (manajer) yang ditunjuk untuk bertindak on the best of interest of stockholders dalam menggapai tujuan utama tersebut memiliki tujuan lain yang mungkin bertentangan. Tujuan lain dari manajer adalah memperbesar skala perusahaan dengan cara ekspansi. Wicaksono (2012) menyebutkan beberapa faktor yang menyebabkan munculnya masalah keagenan yaitu :

a) Moral Hazard

b) Jumlah laba yang ditahan

c) Horizon waktu

d) Penghindaran risiko manajerial

Sen and Meckling dalam Charles (2008) menyatakan bahwa "will lead to a rich theory of organizations which is now lacking in economics and the social sciences generally". Dalam pembahasan ini mengartikan bahwa teori keagenan akan menyebabkan banyak teori dalam kedepannya dan juga ekonomi sekarang menurun sehingga banyak menimbulkan ilmu-ilmu sosial.

3. Kinerja Keuangan 
Laporan keuangan menyajikan informasi mengenai asset, liabilitas, ekuitas, pendapatan, dan beban termasuk keuntungan dan kerugian, kontribusi dari dan distribusi kepada pemilik dalam kapasitasnya sebagai pemilik serta informasi arus kas. Menurut PSAK 1 (IAI, 2015) laporan keuangan yang lengkap terdiri dari :
a) Laporan posisi keuangan
b) Laporan laba rugi komprehensif
c) Laporan perubahan ekuitas
d) Laporan arus kas
e) Catatan atas laporan keuangan
f) Laporan posisi keuangan awal periode

4. Analisis Rasio Keuangan

Analisis rasio keuangan akan menyederhanakan informasi yang menggambarkan hubungan antara pos tertentu dengan pos lainnya yang dilaporkan. Pada dasarnya analisis rasio bisa dikelompokkan kedalam lima macam kategori yaitu likuiditas, profitabilitas, leverage, solvabilitas dan aktivitas (Hanafi dan Halim, 2007:76) namun dalam pembahasan ini peneliti menjelaskan sesuai variabel independen yaitu :

a. Rasio Profitabilitas

Rasio Profitabilitas atau kemampulabaan digunakan untuk mengukur sampai seberapa besar efektivitas manajemen dalam mengelola asset dan equity yang dimiliki perusahaan untuk menghasilkan laba. Dalam rasio ini terdapat 4 rasio yaitu NPM, GPR, ROI, dan ROE, namun dalam penelitian ini diproksikan untuk perhitungan NPM, ROI, dan ROE.

b. Rasio Likuiditas

Rasio likuiditas digunakan untuk mengukur kemampuan perusahaan dalam memenuhi kewajiban jangka pendeknya bila jatuh tempo.Rasio dalam likuiditas dapat dihitung dengan 3 cara yaitu Current Ratio, Quick Ratio, Cash Ratio, namun dalam penelitian ini perhitungan rasio likuiditas diproksikan pada Current Ratio dan Quick ratio.

\section{c. Rasio Leverage}

Rasio leverage digunakan untuk mengukur sampai seberapa besar perusahaan dibiayai oleh hutang. Semakin tinggi rasio ini menunjukkan semakin jelek, karena semakin tinggi pula risiko keuangan yang ditanggung oleh perusahaan. Dalam perhitungan rasio leverage terdapat 3 rasio yaitu DAR, DER, dan Long Term DER. Namun pada penelitian ini diprosikan pada rumus rasio DAR dan DER.

\section{B. Tinjauan Emperis}

Beberapa penelitian yang terdahulu menganalisis tentang pengaruh profitabilitas, likuiditas, dan leverage terhadap kebijakan dividen kas dengan berbagai variabel dan objek sekaligus studi emperis yang berbeda guna melihat perkembangan penelitian dengan judul yang hampir sama. Salah satu penelitian yang dilakukan oleh Kadek Dwi Mahendra Yasa dan Ni Gusti Putu Wirawati (2016) dengan judul " Pengaruh Net Profit Margin, Current Ratio, dan Debt To Equty Ratio Pada Dividend Payout Ratio", diperoleh hasil yaitu variabel net profit margin berpengaruh positif pada dividen payout ratio.

Penelitian yang dilakukan Amilia Herda Novita Sari dan Sisdjiatmo K. Widhaningrat (2014) dengan judul "Analisis Pengaruh Return On Equity, Earning Per Share, Current Ratio, Quick Ratio, Current Earning, dan Growth Opportunity Terhadap Dividend Payout Ratio 
Perusahaan Manufaktur Yang Terdaftar di Bursa Efek Indonesia Periode 2010-2013" diperoleh hasil Quick Ratio berpengaruh signifikan terhdap Dividend Payout Ratio.

Fabio Putra Wijaya dan Atim Djazuli (2013) dengan judul "Pengaruh Return On Investment, Current Ratio, Debt To Equity Ratio Terhadap Dividend Payout Ratio" dengan hasil Return On Investment berpengaruh positif signifikan terhadap Dividen Payout Ratio.

Stefan Yudhanto dan Dr. Siti Aisjah, SE, MS (2013) dengan judul "Pengaruh Net Profit Margin, Return On Asset, Return On Equity, Earning Per Share Terhadap Kebijakan Dividen" diperoleh hasil bahwa secara parsial ROE memiliki pengaruh yang signifikan terhadap kebijakan dividen yang diukur oleh Dividend Payout Ratio.

Fillya Afriani, Ervita Safitri, SE, M.Si, Rini Aprilia, M.Sc (2015) dengan judul “ Pengaruh Likuiditas, Leverage, Profitabilitas, Ukuran Perusahaan dan Growth Terhadap Kebijakan Dividen" dengan hasil bahwa likuiditas, leverage dan ukuran perusahan tidak berpengaruh terhadap Kebijakan dividen

Rialdi Nurraiman (2014) dengan judul "Pengaruh Profitabilitas, Likuiditas, dan Leverage Terhadap Dividend Payout Ratio Pada Perusahaan Manufaktur Yang terdaftar di Bursa efek Indonesia" dengan hasil bahwa DAR tidak berpengaruh terhadap DPR. Hal ini menjelaskan bahwa perubahan DAR tidak mempengaruhi secara menyeluruh terhadap DPR.

\section{Kerangka Konseptual Penelitian}

Berdasarkan latar belakang, rumusan masalah dan landasan teori, maka dapat diketahui kerangka konseptual untuk mengetahui profitabilitas, likuiditas, dan leverage terhadap kebijakan dividen kas seperti yang terlihat pada gambar 2.3.1 sebagai berikut :

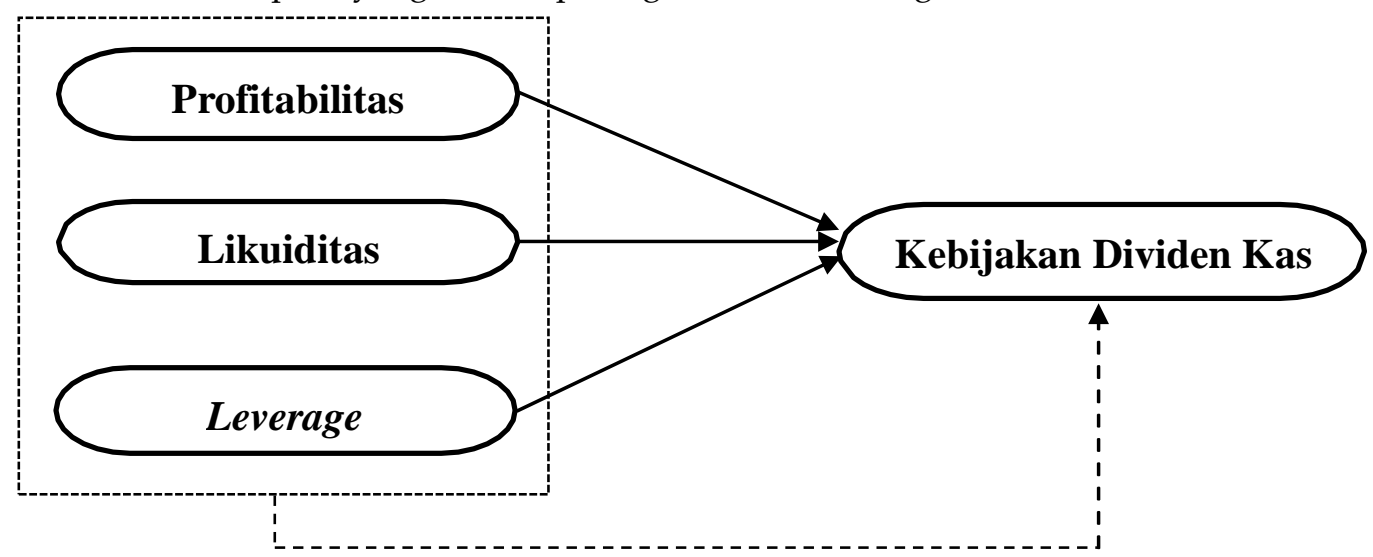

Sumber : Data diolah peneliti, 2016

Keterangan :

$\begin{aligned} & =\text { hubungan secara parsial } \\ & =\text { hubungan secara simultan }\end{aligned}$




\section{Hipotesis}

1. Pengaruh Profitabilitas Terhadap Kebijakan Dividen Kas

a. Net Profit Margin

H1 : Net Profit Margin berpengaruh positif terhadap kebijakan dividen kas

b. Return On Investment

H2 : Return On Investment berpengaruh positif terhadap kebijakan dividen kas

c. Return On Equity

H3 : Return On Equity berpengaruh positif terhadap kebijakan dividen kas

2. Pengaruh Likuiditas Terhadap Kebijakan Dividen Kas

a. Current Ratio

H4: Current Ratio berpengaruh positif terhadap kebijakan dividen kas

b. Quick ratio

H5 : Quick ratio berpengaruh positif terhadap kebijakan dividen kas.

3. Pengaruh Leverage Terhadap Kebijakan Dividen Kas

a. Debt to Asset Ratio

H6 : Debt to Asset Ratio tidak berpengaruh terhadap kebijakan dividen kas

b. Debt to Equity ratio

H7 : Return On Investment berpengaruh positif terhadap kebijakan dividen kas.

4. Profitabilitas, Likuiditas, Dan Leverage Terhadap Kebijakan Dividen Kas.

H8 : Profitabilitas, likuiditas, dan leverage secara bersama-sama atau simultan berpengaruh terhadap kebijakan dividen kas

\section{METODE}

\section{A. Teknik Pengambilan Sampel}

Teknik pengambilan sampel dalam penelitian ini menggunakan purposive sampling yang terdapat pada nonprobability sampling. Purposive sampling adalah suatu teknik penentuan sampel yang dipilih dengan pertimbangan tertentu atau seleksi khusus. Jumlah keseluruhan perusahaan real estate dan properti yang terdaftar di Bursa Efek Indonesia periode 2013 sampai 2015 adalah sebanyak 49 perusahaan, tetapi yang tidak memenuhi kriteria tersebut diatas sebanyak 30 perusahaan. Maka sampel yang digunakan dalam penelitian ini hanya 19 perusahaan pada tahun 2013 sampai tahun 2015.

\section{B. Jenis dan Sumber Data}

1. Jenis Data

Jenis data yang digunakan dalam penelitian ini adalah data kuantitatif deskriptif merupakan data yang berbentuk angka atau bilangan dan dideskripsikan sesuai dengan hasil dan uji statistika. Sesuai dengan bentuknya, data kuantitatif dapat diolah atau dianalisis menggunakan teknik perhitungan matematik atau numerik, statistika dan diklasifikasikan dengan cara deskriptif agar dapat mempermudah pengambilan keputusan kedepannya.

2. Sumber Data

Data yang digunakan dalam penelitian ini adalah data sekunder, karena data penelitian ini diperoleh secara tidak langsung. Sumber data yang digunakan ini diperoleh melalui penelusuran dari media internet seperti situr Indonesian Stock Exchange 
Harrys Amdana Andika Putra, Pengaruh Profitabilitas, Likuiditas, Dan Leverage Terhadap Kebijakan

dan website resmi perusahaan real estate dan properti.

\section{Definisi Operasional Variabel}

1. Variabel Independen

Variabel Independen adalah variabel-variabel yang mempengaruhi atau menjelaskan variabel lain. Penelitian ini menggunakan variabel profitabilitas, likuiditas, dan leverage sebagai variabel independen. Berikut ini merupakan penjelasan dari variabel independen :

a. Profitabilitas

Profitabilitas adalah rasio kemampulabaan digunakan untuk mengukur sampai seberapa besar efektivitas manajemen dalam mengelola asset dan equity yang dimiliki perusahaan untuk menghasilkan laba.
a) Net Profit Margin $=\frac{\text { earning after tax }}{\text { net sales }}$
b) Return On Investment $=\frac{\text { earning before interest and tax }}{\text { total asset }}$
c) Return On Equity = earning after tax

b. Likuiditas

Likuiditas adalah rasio yang digunakan untuk mengukur kemampuan perusahaan dalam memenuhi kewajiban jangka pendeknya bila jatuh tempo.
a) Current Ratio
$=\frac{\text { current assets }}{\text { current liabilitis }}$
b) Quick Ratio
$=\frac{\text { current asset }- \text { inventory }}{\text { current liabilities }}$

c. Leverage

Leverage adalah rasio yang digunakan untuk mengukur sampai seberapa besar perusahaan dibiayai oleh hutang.

a) Debt To Asset Ratio $=\frac{\text { total debt }}{\text { total asset }}$

b) Debt To Equity Ratio $=\frac{\text { total debt }}{\text { equity }}$

2. Variabel Dependen

Variabel dependen adalah tipe variabel yang dijelaskan atau dipengaruhi oleh variabel independen. Penelitian yang menjadi variabel dependen adalah kebijakan dividen kas (Y). Kebijakan dividen kas menyangkut tentang masalah penggunanan laba yang menjadi hak para pemegang saham yaitu pembagian laba dalam jumlah dividen yang dibayarkan tergantung dari kebijakan setiap perusahaan. Dalam penelitian ini Kebijakan dividen kas diukur dengan menggunakan rumus menurut Ahmad sandy (2009) yaitu :

$$
\text { Penilaian Dividen Kas }=\frac{\text { Total dividen tunai }}{\text { Jumlah per lembar saham }}
$$

\section{Teknik Analisis Data}

1. Analisis Regresi Linier Berganda

Penelitian ini menggunakan metode kuantitatif dengan analisis regresi linier berganda. $Y=\alpha+\beta_{1} X_{1}+\beta_{2} X_{2}+\beta_{3} X_{3}+\beta_{4} X_{4}+\beta_{5} X_{5}+\beta_{6} X_{6}+\beta_{7} X_{7}+\epsilon$ Keterangan :

Y : Kebijakan dividen kas(DPR) $\mathrm{X}_{4} \quad: \mathrm{CR}$ 
Harrys Amdana Andika Putra, Pengaruh Profitabilitas, Likuiditas, Dan Leverage Terhadap Kebijakan

Dividen Kas

\begin{tabular}{|c|c|c|}
\hline$\alpha$ & : Konstanta & $X_{5}$ \\
\hline$X_{1}$ & : NPM & $X_{6}$ \\
\hline$X_{2}$ & : ROI & $X_{7}$ \\
\hline$X_{3}$ & : ROE & $\epsilon=$ \\
\hline
\end{tabular}

2. Uji Asumsi Klasik

Uji asumsi klasik merupakan persyaratan statistic yang harus dipenuhi pada analisis regresi linier berganda.

a) Uji Multikolinieritas

Uji Multikolinieritas bertujuan untuk mengetahui apakah ada hubungan antar variabel independen dalam model regresi yang digunakan.

b) Uji Heteroskedastisitas

Uji Heteroskedastisitas bertujuan untuk menguji apakah dalam model regresi terjadi ketidaksamaan variance dari residual satu pengamatan ke pengamatan yang lain (Ghozali, 2009), untuk mengetahui ada tidaknya heteroskedastisistas dilihat melalui hasil uji statistik. Uji statistik yang dilakukan adalah dengan menggunakan Uji Glejser

c) Uji Autokorelasi

Uji autokorelasi diguakan untuk menguji apakah dalam model regresi linier terdapat korelasi antara kesalahan pengganggu pada periode $t$ dengan kesalahan pengganggu pada periode t-1 (sebelumnya). Model regresi yang baik adalah regresi yang bebas dari autokorelasi. Untuk mendeteksi ada tidaknya autokorelasi penelitian ini menggunakan metode uji Durbin-Watson (DW test). Metode DW menggunakan titik kritis yaitu batas bawah dl dan batas atas dU. H0 diterima jika nilai DW lebih besar dari batas atas nilai DW pada tabel DW.

d) Uji Normalitas

Uji normalitas adalah uji untuk mengetahui apakah data empirik yang didapatkan dari lapangan itu sesuai dengan distribusi teoritik tertentu.

\section{E. Uji Hipotesis}

1. Uji Koefisien Determinasi

Pengukuran koefisien determinasi dilakukan untuk mengetahui presentase pengaruh variabel independen terhadap perubahan variabel dependen. Hal ini diketahui seberapa besar variabel dependen mampu dijelaskan oleh variabel independennya, sedangkan sisanya dijelaskan oleh sebab-sebab lain diluar model.

2. Ujit

Uji $t$ bertujuan untuk menguji bagaimana pengaruh masing-masing variabel bebas secara parsial terhadap variabel terikatnya. Uji ini dapat dilakukan dengan membandingkan $\mathrm{t}$ hitung dengan $\mathrm{t}$ tabel atau dengan melihat kolom signifikansi $<0,05$ pada masing-masing t hitung, jika signifikansi $<0,05$ (5\%) maka hipotesis diterima dan secara parsial variabel bebas berpengaruh secara signifikan terhadap variabel terikat, begitu juga sebaliknya.

3. Uji F

Uji F digunakan untuk menguji tingkat pengaruh variabel independen terhadap variabel dependen secara bersama-sama. Dalam uji $F$ penggunaan tingkat 
Harrys Amdana Andika Putra, Pengaruh Profitabilitas, Likuiditas, Dan Leverage Terhadap Kebijakan

Dividen Kas

signifikannya menggunakan 0,05 (5\%).

\section{PEMBAHASAN}

\section{A. Deskripsi Data}

Populasi dalam penelitan ini adalah perusahaan-perusahan yang terdaftar dalam Bursa efek Indonesia dengan sub sektor perusahaan real estate dan properti yang berjumlah sebanyak 49 perusahaan. Periode yang digunakan dalam penelitian ini dimulai tahun 2013 sampai 2015. Penelitian ini menggunakan purposive sampling yaitu sampel yang dipilih dengan menggunakan pertimbangan- pertimbangan tertentu yang disesuaikan dengan tujuan penelitian. Tahun 2016 terdapat 49 perusahaan real estate dan properti yang terdaftar di BEI, namun terdapat 30 perusahaan yang tidak dimasukkan dikarenakan tidak sesuai dengan kriteria tujuan penelitian Dan sisanya adalah perusahaan-perusahaan yang terpilih sesuai criteria yang dibutuhkan oleh peneliti yaitu sebanyak 19 perusahaan yang menjadi sampel dalam penelitian ini.

\section{B. Analisis Hasil Penelitian}

\section{Uji Asumsi Klasik}

Uji asumsi klasik merupakan persyaratan statistik yang harus dipenuhi pada analisis regresi linier berganda. Untuk melakukan pengujian hipotesis dalam penelitian, dengan melakukan pengujian asumsi klasik sebagai berikut : uji multikolinieritas, heteroskedastisitas, autokorelasi, dan normalitas

a. Uji Multikolonieritas

Uji Multikolinieritas bertujuan untuk mengetahui apakah ada hubungan antar variabel independen dalam model regresi yang digunakan. Seharusnya tidak berhubungan. Untuk mengetahui digunakan pendekatan Variance Inflation Factor (VIF) (Ghozali, 2009).

Tabel 4.2.1

Hasil Uji Multikolonieritas

\begin{tabular}{|c|c|c|c|}
\hline \multicolumn{4}{|c|}{ Coefficientsa } \\
\hline \multirow{2}{*}{\multicolumn{2}{|c|}{ Model }} & \multicolumn{2}{|c|}{ Collinearity Statistics } \\
\hline & & Tolerance & VIF \\
\hline 1 & (Constant) & & \\
\hline & X1_NPM & .210 & 4.763 \\
\hline & X2_ROI & .419 & 2.385 \\
\hline & X3_ROE & .179 & 5.578 \\
\hline & X4_CR & .358 & 2.790 \\
\hline & X5_QR & .281 & 3.55 \\
\hline & X6_DAR & .212 & $4.72:$ \\
\hline & X7 DER & .209 & 4.788 \\
\hline
\end{tabular}

Sumber : data sekunder diolah melalui SPSS 16,2016

Bedasarkan output diketahui bahwa nilai tolerace NPM sebesar 0.210 lebih besar dari 0.10, nilai tolerance ROI sebesar 0,419 lebih besar dari 0,10, nilai tolerance ROE sebesar 0,179 lebih besar dari 0,10, nilai tolerance CR sebesar 0,358 lebih besar dari 0,10, nilai tolerance QRI sebesar 0,281 lebih besar dari 0,10, nilai tolerance DAR 
Harrys Amdana Andika Putra, Pengaruh Profitabilitas, Likuiditas, Dan Leverage Terhadap Kebijakan

Dividen Kas

sebesar 0,212 lebih besar dari 0,10, dan nilai tolerance DER sebesar 0,209 lebih besar dari 0,10. Jadi semua nilai tolerance variabel independen lebih besar dari 0,10.

Nilai VIF variabel NPM sebesar 4,763 lebih kecil dari 10,00, nilai VIF variabel ROI sebesar 2,385 lebih kecil dari 10,00, nilai VIF variabel ROE sebesar 5,578 lebih kecil dari 10,00, nilai VIF variabel CR sebesar 2,790 lebih kecil dari 10,00, nilai VIF variabel QR sebesar 3,555 lebih kecil dari 10,00, nilai VIF variabel DAR sebesar 4,725 lebih kecil dari 10,00, nilai VIF variabel DER sebesar 4,788 lebih kecil dari 10,00. Jadi berdasarkan nilai diatas, maka disimpulkan bahwa tidak terjadi multikolonieritas.

b. Uji Heteroskedastisitas

Pengujian heteroskedastisitas ini pada dasarnya bertujuan untuk menguji apakah dalam model regresi terjadi ketidaksamaan variance dari residual atau pengamatan ke pengamatan yang lain.

Gambar 4.2.2

Gambar Uji Hateroskedastisitas

Coefficients $^{\mathrm{a}}$

\begin{tabular}{|c|c|c|c|c|c|}
\hline \multirow[t]{2}{*}{ Model } & \multicolumn{2}{|c|}{$\begin{array}{l}\text { Unstandardized } \\
\text { Coefficients }\end{array}$} & \multirow{2}{*}{\begin{tabular}{l}
$\begin{array}{l}\text { Standardiz } \\
\text { ed }\end{array}$ \\
Coefficient \\
s \\
\multicolumn{1}{c}{ Bet } \\
a
\end{tabular}} & \multirow[t]{2}{*}{$\mathrm{t}$} & \multirow[t]{2}{*}{ Sig. } \\
\hline & B & $\begin{array}{l}\text { Std. } \\
\text { Error }\end{array}$ & & & \\
\hline 1 (Constant) & 5.940 & 1.794 & & 3.310 & .002 \\
\hline X1_NPM & 2.326 & 3.940 & .176 & .590 & .558 \\
\hline X2_ROI & 11.258 & 7.218 & .329 & 1.560 & .125 \\
\hline X3_ROE & -6.439 & 5.678 & -.366 & -1.134 & .262 \\
\hline X4_CR & .843 & 1.130 & .170 & .745 & .460 \\
\hline X5_QR & -.619 & 1.577 & -.101 & -.392 & .697 \\
\hline X6_DAR & -14.208 & 7.624 & -.554 & -1.863 & .068 \\
\hline X7_DER & 4.268 & 2.735 & .467 & 1.561 & .125 \\
\hline
\end{tabular}

Sumber : data sekunder diolah melalui SPSS 16,2016 
Berdasarkan output diatas diketahui bahwa signifikasi variabel NPM sebesar 0,558 lebih besar dari 0,05, nilai signifikasi variabel ROI sebesar 0,125 lebih besar dari 0,05, nilai signifikasi variabel ROE sebesar 0,262 lebih besar dari 0,05, nilai signifikasi variabel CR sebesar 0,460 lebih besar dari 0,05, nilai signifikasi variabel QR sebesar 0,697 lebih besar dari 0,05, nilai signifikasi variabel DAR sebesar 0,068 lebih besar dari 0,05, nilai signifikasi variabel DER sebesar 0,125 lebih besar dari 0,05 . Artinya bahwa, semua variabel independen data residual tidak terjadi heteroskedastisitas.

c. Uji Autokorelasi

Autokorelasi adalah suatu keadaan dimana terjadinya korelasi antara residual pada satu pengamatan dengan pengamatan lain pada model regresi.

Tabel 4.2.3

Hasil Uji Autokorelasi

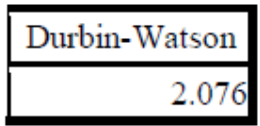

Sumber : Data sekunder diolah melalui SPSS 16, 2016

Berdasarkan nilai diatas, diketahui nilai Durbin Watson sebesar 2,076 nilai ini akan dibandingkan dengan nilai tabel dengan menggunakan signifikansi 5\%. Untuk jumlah sampel $n=57$, jumlah variabel independen $(k)=7$, nilai $d L=1,311$ dan $d U=$ 1,856. Nilai DW 2,076 lebih besar dari batas atas (dU) yaitu 1,856 dan kurang dari (4dU) 4-1856 = 2,144. Maka dapat disimpulkan bahwa tidak terdapat autokorelasi.

d. Uji Normalitas

Uji normalitas bertujuan untuk mengetahui apakah data penelitian terdistribusi normal atau tidak, sebab, dalam statistic parametric deskriptif data yang normal adalah suatu keharusan dan merupakan syarat yang mutlak yang harus terpenuhi.

Tabel 4.2.4 Uji

Normalitas

One-Sample Kolmogorov-Smirnov Test

\begin{tabular}{|ll|r|}
\hline & & $\begin{array}{c}\text { Unstandardi } \\
\text { zed } \\
\text { Residual }\end{array}$ \\
\hline $\mathrm{N}$ & Mean & 57 \\
Normal Parameters & & .0000000 \\
& Std. Deviation & 6.42371950 \\
Most Extreme Differences & Absolute & .077 \\
& Positive & .077 \\
& Negative & -.072 \\
Kolmogorov-Smirnov Z & & .578 \\
Asymp. Sig. (2-tailed) & & .892 \\
\hline
\end{tabular}

Sumber : Data sekunder diolah melalui SPSS 16, 2016 
Berdasarkan hasil output uji normalitas diatas, diketahui bahwa signifikan sebesar 0,893 lebih besar dari 0,05, sehingga dapat disimpulkan bahwa data yang diuji terdistribusi normal. Kemudian berdasarkan analisis grafik dapat disajikan normal p-plot of regression standardized residual yang dapat digambarkan sebagai berikut :

\section{Gambar 4.2.1}

Uji Normal Propability Plot
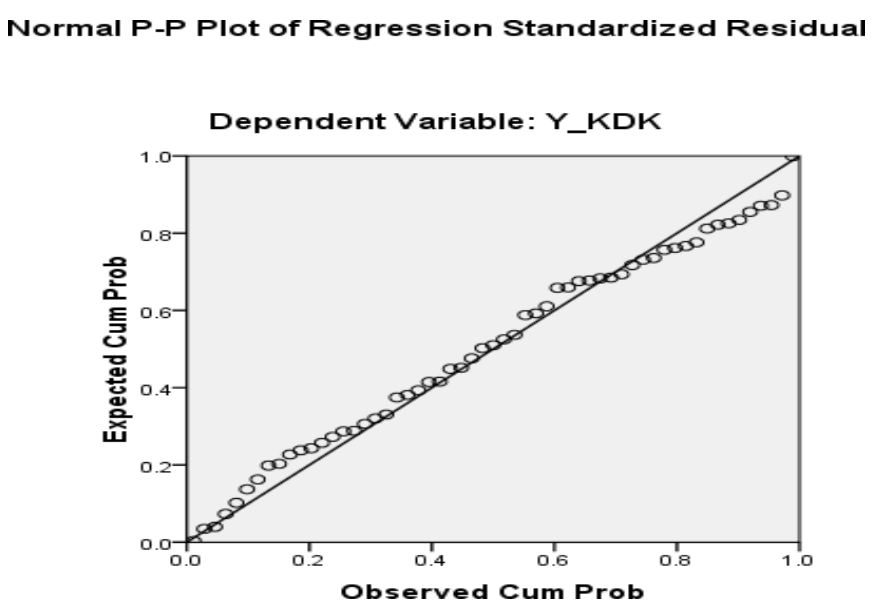

Sumber : Data sekunder dolah melalui SPSS 16, 2016

Selanjutnya dapat disajikan diagram normal P-Plot of Regression Standardized Residual data menyebar di sekitar garis diagonal dan mengikuti arah garis diagonal maka model regresi memenuhi standar normalitas.

\section{Pengujian Hipotesis}

1. Uji Koefisien Determinasi

Uji ini dilakukan untuk mengukur kemampuan variabel independen, yaitu NPM, ROI, ROE, CR, QR, DAR, dan DER dalam menjelaskan variasi variabel dependen Kebijakan Dividen Kas. Berikut ini adalah hasil output uji koefisien determinasi, dapat dilihat seperti dibawah ini :

Tabel 4.2.5

\section{Hasil Uji Koefisien Determinasi}

\begin{tabular}{|l|r|r|r|r|}
\hline Model & \multicolumn{1}{|c|}{ R } & R Square & Adjusted R Square & $\begin{array}{c}\text { Std. Error of the } \\
\text { Estimate }\end{array}$ \\
\hline 1 & $.928^{\mathrm{a}}$ & .861 & .842 & 6.86725 \\
\hline
\end{tabular}

Sumber : Data sekunder diolah melalui SPSS 16, 2016

Hasil output SPSS pada tabel diatas menunjukkan besarnya adjusted $R$ Square sebesar 842. hal ini berarti hanya $84,2 \%$ variasi kebijakan dividen kas yang dapat dijelaskan oleh variasi variabel independen yaitu NPM, ROI, ROE, CR, QR, DAR, dan DER, sedangkan sisanya 25,8\% masih terdapat variasi variabel terikat yang belum mampu dijelaskan oleh variabel bebas dalam model penelitian ini

2. Uji t

Uji t bertujuan untuk menguji seberapa jauh pengaruh variabel independen secara individual yaitu NPM, ROI, ROE, CR, QR, DAR, dan DER dalam menerangkan variasi variabel dependen kebijakan dividen kas, berikut ini hasil uji t dapat dilihat dibawah ini : 
Tabel 4.2.6

Hasil Uji $\mathbf{t}$

Coefficients $^{\mathrm{a}}$

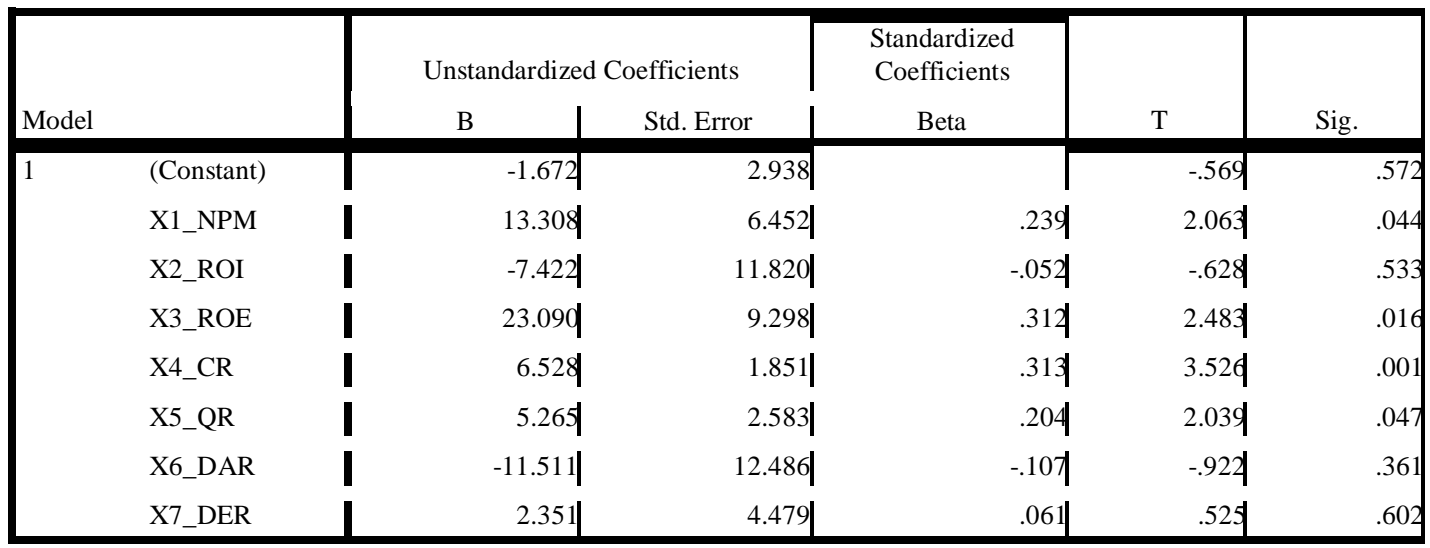

Sumber : data sekunder diolah melalui SPSS 16, 2016

Berdasarkan hasil analisis regresi yang diperoleh nilai t hitung yaitu sebesar 2,063>2,010 dan nilai signifikasi (sig.) 0,044<0,05. maka hal ini dapat disimpulkan bahwa NPM berpegaruh positif signifikan terhadap kebijakan dividen kas. Hal ini berarti Ha diterima. Berdasarkan hasil analisis regresi yang diperoleh nilai $\mathrm{t}$ hitung yaitu sebesar - 0,628<2,010 dan nilai signifikasi (sig.) 0,533>0,05. maka hal ini dapat disimpulkan bahwa

ROI tidak berpegaruh terhadap kebijakan dividen kas. Hal ini berarti Ho ditolak.

Berdasarkan hasil analisis regresi yang diperoleh nilai $t$ hitung yaitu sebesar 2,483>2,010 dan nilai signifikasi (sig.) 0,016<0,05 maka hal ini dapat disimpulkan bahwa ROE berpegaruh positif signifikan terhadap kebijakan dividen kas. Hal ini berarti Ha diterima. Berdasarkan hasil analisis regresi yang diperoleh nilai $\mathrm{t}$ hitung yaitu sebesar 3,526>2,010 dan nilai signifikasi (sig.) $0,001<0,05$.. maka hal ini dapat disimpulkan bahwa

CR berpegaruh positif signifikan terhadap kebijakan dividen kas. Hal ini berarti Ha diterima. Berdasarkan hasil analisis regresi yang diperoleh nilai $t$ hitung yaitu sebesar

2,039>2,010 dan nilai signifikasi (sig.) 0,047<0,05.. maka hal ini dapat disimpulkan bahwa QR berpegaruh positif signifikan terhadap kebijakan dividen kas. Hal ini berarti Ha diterima.

Berdasarkan hasil analisis regresi yang diperoleh nilai thitung yaitu sebesar 0,922<2,010 dan nilai signifikasi (sig.) 0,361>0,05 maka hal ini dapat disimpulkan bahwa DAR tidak berpegaruh terhadap kebijakan dividen kas. Hal ini berarti Ha diterima.

Berdasarkan hasil analisis regresi yang diperoleh nilai $t$ hitung yaitu sebesar 0,061<2,010 dan nilai signifikasi (sig.) 0,525>0,05 maka hal ini dapat disimpulkan bahwa DER tidak berpegaruh terhadap kebijakan dividen kas. Hal ini berarti Ha diterima.

3. Uji $\mathrm{F}$

Uji F dilakukan dengan tujuan menguji apakah semua variabel independen yang dimasukkan dalam model mempunyai pengaruh secara bersama-sama terhadap 
variabel dependen. Berikut hasil uji F :

\section{Tabel 4.2.7 \\ Hasil Uji F}

Anerab

\begin{tabular}{|c|c|c|c|c|c|}
\hline Model & Sum of Squares & $\mathrm{Df}$ & Mean Square & $\mathrm{F}$ & Sig. \\
\hline Regression & 14355.726 & 7 & 2050.818 & 43.487 & \\
\hline Residual & 2310.794| & 49 & 47.159 & & \\
\hline Total & 16666.520 & 56 & & & \\
\hline
\end{tabular}

Sumber : data sekunder diolah melalui SPSS 16, 2016

Hasil uji statistik F menghasilkan F hitung 43,487 dan F tabel sebesar 2,203 Maka diketahui $\mathrm{F}$ hitung 43,487>2,203, artinya hipotesis diterima dan nilai signifikasi 0,000 . Nilai probabilitas pengujian yang lebih kecil dari $=0,05$, maka model regresi menunjukkan bahwa secara bersama-sama (simultan) NPM, ROI, ROE, CR, QR, DAR, dan DER berpengaruh signifikan terhadap kebijakan dividen kas.

4. Analisis Regresi Linier Berganda

Berdasarkan dengan data yang ada pada tabel coefficient dapat diperoleh persamaan regresi sebagai berikut ini :

$$
\begin{aligned}
& Y=-1,672+13,308 X_{1}-7,422 X_{2}+23.090 X_{3}+6,528 X_{4}+5,265 X_{5} \\
& -11,511 X_{6}+4,479 X_{7}
\end{aligned}
$$

\section{Pembahsan Hipotesis}

1. Pengaruh Net Profit Margin Terhadap Kebijakan Dividen Kas

Hasil dari regresi menunjukkan nilai t hitung sebesar 2,063 dengan probabilitas signifikansi adalah 0,044 berada lebih rendah pada $=0,05$ (standar variabel independen berpengaruh atau tidak terhadap dependen). Jadi dapat disimpulkan bahwa NPM berpengaruh terhadap kebijakan dividen kas.

Hal ini dikararenakn net profit margin adalah pembagian pendapatan atau penjualan bersih dengan laba setelah pajak dalam hal ini berpengaruh terhadap harga saham, kebijakan dividen kas pun dipengaruh juga terhadap seberapa besar pendapatan perusahaan dalam tahun berjalan. Hasil penelitian ini mendukung Kadek Dwi Mahendra Yasa tahun 2016 menghasilakn bahwa variabel NPM berpengaruh positif signifikan terhadap DPR.

2 Pengaruh Return On Investment Terhadap Kebijakan Dividen Kas

Hasil dari regresi menunjukkan nilai t hitung sebesar -0,628 dengan probabilitas signifikansi adalah 0,533 berada lebih tinggi pada $=0,05$ (standar variabel independen berpengaruh atau tidak terhadap dependen). Jadi dapat disimpulkan bahwa ROI tidak berpengaruh terhadap kebijakan dividen kas.

Hal ini semakin tinggi tingkat investasi perusahaan maka dana yang laba yang digunakan bisa dilarikan untuk kegiatan investasi sehingga mengakibatkan laba yang digunakan berkurang untuk pembagian dividen terhadap pemegang saham. Menurut Ghozali (2009) tidak berpengaruhnya variabel bisa disebabkan kurangnya sampel penelitian.Hasil penelitian ini tidak mendukung penelitian Atim Djazuli tahun 2012 menghasilakn bahwa variabel ROI berpengaruh positif signifikan terhadap DPR, namun penelitian ini mendukung penelitian Nor Apandi (2012) yang menghasilkan secara parsial ROI tidak berpengaruh terahadap dividen payout ratio. 
3. Pengaruh Return On Equity Terhadap Kebijakan Dividen Kas

Hasil dari regresi menunjukkan nilai t hitung sebesar 2,438 dengan probabilitas signifikansi adalah 0,16 berada lebih rendah pada $=0,05$ (standar variabel independen berpengaruh atau tidak terhadap dependen). Jadi dapat disimpulkan bahwa ROE berpengaruh terhadap kebijakan dividen kas.

Tingkat laba perusahaan mampu memberikan gambaran baik kepada manajemen maupun para investor mengenai pertumbuhan perusahaan serta kondisi keuangan pada periode tertentu. Selain itu faktor lain yang perlu dipertimbangkan manajemen perusahaan adalaha stabilisasi dividen yang dibayarkan akan mengurangi ketidakpastian dari profitabilitas perusahaan. Hasil Penelitian ini mendukung penelitian Stefan Yudhanto tahun 2012 menghasilakn bahwa variabel ROE berpengaruh positif signifikan terhadap kebijakan dividen.

4. Pengaruh Current Ratio Terhadap Kebijakan Dividen Kas

Hasil dari regresi menunjukkan nilai t hitung sebesar 3,526 dengan probabilitas signifikansi adalah 0,001 berada lebih rendah pada $=0,05$ (standar variabel independen berpengaruh atau tidak terhadap dependen). Jadi dapat disimpulkan bahwa CR berpengaruh terhadap kebijakan dividen kas.

Menurut Griffin (2010) likuiditas merupakan daya tarik bagi para investor, jika perusahaan mampu membayarkan kewajibannya maka perusahaan tersebut likuid dan juga diindikasikan bahwa salah satu faktor perusahaan mampu membayar dividen adalah dengan tingkat likuiditasnya. .Hasil Penelitian ini mendukung penelitian Komang Ayu Novita dkk tahun 2015 menghasilakn bahwa variabel CR berpengaruh positif signifikan terhadap kebijakan dividen dikarenakan pada hasil penelitian ini tingkat profitabilitas perusahaan mempengaruhi pada kebijakan dividen dengan proksi CR.

5. Pengaruh Quick Ratio Terhadap Kebijakan Dividen Kas

Hasil dari regresi menunjukkan nilai thitung sebesar 2,039 dengan probabilitas signifikansi adalah 0,047 berada lebih rendah pada $=0,05$ (standar variabel independen berpengaruh atau tidak terhadap dependen). Jadi dapat disimpulkan bahwa QR berpengaruh terhadap kebijakan dividen kas.

Hal ini disebabkan karena dividen digunakan untuk mengurangi agency conflict antara manager dan shareholder. Kelebihan likuiditas yang dimiliki oleh perusahaan ditransfer kepada shareholder melalui dividen. Hasil penelitian ini mendukung penelitian Novita Sari dkk pada tahun 2014 yang menghasilkan variabel QR berpengaruh positif signifikan terhadap DPR.

6. Pengaruh Debt to Asset Ratio Terhadap Kebijakan Dividen Kas

Hasil dari regresi menunjukkan nilai t hitung sebesar $-0,922$ dengan probabilitas signifikansi adalah 0,361 berada lebih tinggi pada $=0,05$ (standar variabel independen berpengaruh atau tidak terhadap dependen). Jadi dapat disimpulkan bahwa DAR tidak berpengaruh terhadap kebijakan dividen kas.

Hasil penelitian ini terjadi dikarenakan pada setiap perusahaan, jika terjadi kenaikan pada DAR maupun penurunan tidak ada terjadi perubahan pada kebijakan dividen. Hal ini ini disebabkan bahwa kebijakan dividen hanya berpengaruh terhadap 
Harrys Amdana Andika Putra, Pengaruh Profitabilitas, Likuiditas, Dan Leverage Terhadap Kebijakan

Dividen Kas

tingkat likuiditas maupun profitabilitas setiap perusahaan. Namun pada tingkat leverage yaitu diproksikan pada DAR tidak terdapat pengaruh terhadap kebijakan dividen kas. Hasil penelitian ini mendukung penelitian Rialdi Nurraiman pada tahun 2014 yang menghasilkan variabel DAR tidak berpengaruh signifikan terhadap DPR.

7. Pengaruh Debt to Equity Ratio Terhadap Kebijakan Dividen Kas

Hasil dari regresi menunjukkan nilai t hitung sebesar 0,525 dengan probabilitas signifikansi adalah 0,602 berada lebih tinggi pada $=0,05$ (standar variabel independen berpengaruh atau tidak terhadap dependen). Jadi dapat disimpulkan bahwa DER tidak berpengaruh terhadap kebijakan dividen kas.

Hasil penelitian ini mendukung penelitian Fillya Afriani dkk pada tahun 2014 yang menghasilkan variabel DER tidak berpengaruh signifikan terhadap DPR. Dikarenakan tingkat leverage yang diproksikan oleh DER semakin tinggi atau turun maka dividen kas yang diberikan tetap.

8. Pengaruh Profitabilitas, Likuiditas, dan Leverage Terhadap Kebijakan Dividen Kas

Pengaruh penerapan NPM, ROI, dan ROE atau profitabilitas, CR dan QR atau Likuiditas, dan DAR dan DER atau Leverage berpengaruh signifikan terhadap kebijakan dividen kas pada perusahaan real estate dan properti periode 2013-2016. Tabel 4.2.7 bahwa $\mathrm{F}$ hitung sebesar 43,487 dan signifikan 0,000 maka nilai probabilitas pengujian yang lebih kecil dari $=0,05$ (standar variabel independen berpengaruh atau tidak terhadap dependen). Selain itu dalam sikap pemegang saham atau para investor lebih melihat tentang seberapa besar para menejerial mengelola perusahaan dapat dilihat dari profit dan likuiditas perusahaa. Selain itu dari segi leverage para pemegang saham juga melihat bagaimana pihak perusahaan mengelola perusahaan dengan pendanaan dari pihak ketiga. Dilihat dari pengelolaan perusahaan dengan memberikan profit dan likuid yang dapat berpengaruh pada pembagian dividen kas perusahaan, sehingga variabel NPM, ROI, dan ROE atau profitabilitas, CR dan QR atau Likuiditas, dan DAR dan DER atau Leverage berpengaruh signifikan terhadap kebijakan dividen kas pada perusahaan real estate dan properti periode 2013-2016.

\section{KESIMPULAN}

\section{A. Kesimpulan}

Penelitian menguji pengaruh profitabilitas, likuiditas, dan leverage terhadap kebijakan dividen kas. Dimana variabel-variabel tersebut diproksikan dalam beberapa rumus yaitu profitabilitas diproksikan dengan NPM, ROI, dan ROE, serata Likuiditas diproksikan dengan $\mathrm{CR}$ dan $\mathrm{QR}$, serta variabel Leverage diproksikan dengan DAR dan DER. Berikut ini adalah kesimpulan yang dapat diambil dari hasil penelitian :

1. Profitabilitas yang diproksikan dengan Net Profit Margin (NPM) berpengaruh positif signifikan terhadap kebijakan dividen kas.

2. Profitabilitas yang diproksikan dengan Return On Investment (ROI) tidak berpengaruh signifikan terhadap kebijakan dividen kas.

3. Profitabilitas yang diproksikan dengan Return On Equity (ROE) berpengaruh positif signifikan terhadap kebijakan dividen kas.

4. Likuiditas yang diproksikan dengan Current Ratio (CR) berpengaruh positif signifikan terhadap kebijakan dividen kas. 
5. Likuiditas yang diproksikan dengan Quick Ratio (QR) berpengaruh positif signifikan terhadap kebijakan dividen kas.

6. Leverage yang diproksikan dengan Debt to Asset Ratio (DAR) tidak berpengaruh signifikan terhadap kebijakan dividen kas.

7. Leverage yang diproksikan dengan Debt to Equity Ratio (DER) tidak berpengaruh signifikan terhadap kebijakan dividen kas.

8. Secara simultan atau bersama-sama profitabilitas, likuiditas, dan leverage berpengaruh signifikan terhadap kebijakan dividen kas.

\section{B. Saran}

Saran yang dapat diberikan kepada peneliti selanjutnya dan pembaca berdasarkan hasil penelitian ini guna memberikan penelitian yang lebih valid dan lebih lengkap dalam pengambilan keputusan selanjutnya yaitu untuk memberikan acuan jurnal penelitian untuk penelitian selanjutnya yang memakai variabel-variabel dalam penelitan ini. Berdasarkan hasil penelitian dan pembahasan sebelumnya dapat ditarik beberap saran sebagai berikut :

1. Penelitiannya selanjutnya disarankan untuk melakukan penelitian dengan menggunakan periode- periode pengamatan yang lebih lama agar dapat memprediksi hasil penelitian jangka panjang dengan periode yang lebih panjang diketahui pertumbuhan perusahaan dalam jangka panjang.

2. Penelitian selanjutnya disarankan menambah beberapa proksi dari profitabilitas yaitu proksi Growth Profit Ratio, likuiditas yaitu proksi Cash Ratio, dan leverage diproksikan dengan Long Term Debt to Equity Ratio.

3. Penelitian selanjutnya perlu mempertimbangkan sampel artinya sampel penelitian lebih diperbanyak atau lebih banyak dari sampel penelitian ini tidak hanya populasi Real Estate dan Properti saja, bisa memakai populasi lebih luas sehingga sampel lebih banyak dan lebih luas. Hal ini bertujuan agar memberikan kesimpulan yang dihasilkan memiliki cakupan lebih luas

\section{DAFTAR PUSTAKA}

Asyik, Nur Fadjrih, dan Ahmad Sandy. 2009. "Pengaruh Profitabilitas dan Likuiditas Terhadap Kebijakan dividen kaskasKas Pada Perusahaan Otomotif. Jurnal Ilmu dan Riset Akuntansi Vol; 1 No. 1. Januari 2009 : 58-76. Surabaya.

Darminto. 2008. "Pengaruh Profitabilitas, Likuiditas, Struktur Modal, dan Struktur Kepemilikan Saham Terhadap Kebijakan Dividen. Jurnal Ilmu-ilmu Sosial (Social Sciences). Vol. 20 No. 2. Agustus 2008. Malang

Fillya Afriani, Ervita Safitri, dan Rini Aprilia. 2015. "Pengaruh Likuiditas, Leverage, Profitabilitas, Ukuran Perusahaan, dan Growth Terhadap Kebijakan Dividen. Artikel Jurusan Manajemen Sekolah Tinggi Ilmu Ekonomi MDP Palembang.

Hanafi, Mahmud M dan Abdul Halim. 2007. Analisis Laporan Keuangan. UPP YKPN. Yogyakarta.

Hill, Charles W. L. and Thomas M. Jones. 2008."Stakeholder-Agency Theory". Journal of Management Studies 29:2. March 2008. School of Business Administration. University Washington.

Ikatan Akuntan Indonesia. Standar Akuntansi Keuangan per efektif 1 Januari 2015. Jakarta. 2014 
Harrys Amdana Andika Putra, Pengaruh Profitabilitas, Likuiditas, Dan Leverage Terhadap Kebijakan

Dividen Kas

Imam Ghozali. 2009. Aplikasi Analisis Multivariate dengan Program SPSS. Badan Penerbit Universitas Diponegoro. Semarang

Rialdi Nurraiman. 2014. “Pengaruh Profitabiltas, Likuiditas, dan Laverage Terhadap Devidend

Payout Ratio Pada Perusahaan Manufaktur yang terdaftar di Bursa Efek Indonesia. Skripsi Universitas Widyatama. Bandung.

Sari, Amilia Herda Novita dan sisdjiatmo K. Widhaningrat. 2014. "Analisis Pengaruh Return

On Equity, Earning Per Share, Current Ratio, Quick Ratio, Current Earning, dan Growth Opportunity Terhadap Dividend Payout Ratio Perusahaan Manufaktur Yang Terdaftar di Bursa Efek Indonesia Periode 2010-2013". Fakultas Ekonomi. Universitas Indonesia. Jakarta

Sunariyah. 2010. Pengantar Pengetahuna Pasar Modal . Edisi Ke Enam. UPP-AMP YKPN. Yogyakarta.

Uswatun Khasanah. 2009. Analisis Pengaruh Investasi, Likuiditas, Profitabilitas, dan Ukuran Perusahaan Terhadap Kebijakan Dividend Payout Ratio Pada Perusahaan Yang Terdaftar di Jakarta Islamic Index Tahun 2000-2004. Skripsi Fakultas Syariah Universitas Islam Negeri Sunan Kalijaga Yogyakarta.

Utaminingtyas, Tri Hesti, Indah Sulistyowati, dan Ratna Anggraini. 2010. "Pengaruh Profitabilitas, Leverage, dan Growth Terhadap Kebijakan dividen kaskasdengan Good Corporate Governance sebagai Variabel Intervening. Simposium Nasional Akuntanis XIII Purwokerto.

Wijaya, Fabio Putra dan Atim Djazuli. 2013. "Pengaruh Return On Investment, Current Ratio, Debt To Equity Ratio Terhadap Dividend Payout Ratio". Fakultas Ekonomi dan Bisnis. Universitas Brawijaya. Malang

www.finance.yahoo.com diakses pada bulan November 2016 www.idx.co.id diakses pada bulan November 2016 www.sahamok.com diakses pada bulan November 2016

Yasa, Kadek Dwi Mahendra dan Ni Gusti Putu Wirawati. 2016. "Pengaruh Net Profit Margin, Current Ratio, dan Debt To Equity Ratio Pada Dividend Payout Ratio". E-Jurnal Akuntansi Universitas Udayana. Vol 16.2 Agustus: 921-950

Yudhanto, Stefan dan Dr. Siti Aisjah, SE, MS. 2013."Pengaruh Pengaruh Net Profit Margin, Return On Asset, Return On Equity, Earning Per Share Terhadap Kebijakan Dividen". Fakultas Ekonomi dan Bisnis. Universitas Brawijaya. Malang 